UDC 339.9

DOI: https://doi.org/10.32782/2413-9971/2020-31-15

Piatkov Artem

Student

Odesa I. I. Mechnikov National University

Rodionova Tatiana

Candidate of Economic Sciences,

Senior Lecturer at Department of World Economy

and International Economic Relations

Odesa I. I. Mechnikov National University

Пятков А. М.

студент

Одеського начіонального університету імені I. I. Мечникова

Родіонова Т. А.

кандидат економічних наук, доцент кафедри світового господарства

і міжнародних економічних відносин

Одеського начіонального університету імені I. I. Мечникова

\title{
IMPACT OF FOREIGN INVESTMENT RETURNS ON THE FOREIGN ECONOMIC POSITIONS OF GEORGIA, MOLDOVA AND UKRAINE
}

\begin{abstract}
Summary. This article analyses the structure and impact of investment income from foreign investment on the foreign economic positions of Georgia, Moldova and Ukraine, as well as the financial stability of countries. A comparative analysis based on net investment position to GDP showed that Georgia is becoming more and more dependent on foreign investment, while in Ukraine, the net investment position indicator is improving and the country is more financially sustainable than Georgia and Moldova.Vector auto-regression model (VAR) showed that the increase in Georgia's external debt is mostly influenced by direct and portfolio investments. For Moldova, there is a mutual causality between the level of external debt and the income of portfolio and other investments. At the same time, the model did not show the relationship between Ukrainian external debt and investment income.
\end{abstract}

Keywords: foreign investment, external positions, debt, income, repayments.

Problem statement. The expansion of foreign direct investment (FDI) began after World War II, when globalization was restored at an accelerated pace. The increasing importance of multinational corporations (MNCs) and foreign investment in the 1950s and 1960s, especially FDI flows from the United States to the European countries, prompted many researchers to study the problem of MNCs and the existence of international production. As a result, many theories have been formulated to explain the international movement of capital.

Based on the experience of the world economy, foreign direct investment (FDI) contributes to economic growth. Foreign direct investment affects not only the capital of the host country, but also attempts to gain access to new markets, acquire the latest technologies and experience, and generate income. FDI allows us to find acceptable solutions to various problems. FDI provides valuable capital to stimulate economic growth and development and brings technology along with knowledge. In addition, new markets around the world can become more accessible through FDI. In fact, several factors, such as the level of knowledge and skills of staff, as well as aspects of productivity, have a significant impact on attracting and supporting foreign direct investment.

According to UNCTAD, foreign direct investment flows to Georgia reached 1.2 billion USD in 2018 and will grow moderately in the coming years, supported by rising commodity prices and stronger economic growth. FDI inflows to Moldova have declined in recent years: before the crisis, the average annual figure was estimated at 330 million USD, but according to the UNCTAD world investment report for 2019, the inflow was 228 million USD. In 2018, compared to only 163 million USD in the previous year.
The total volume of FDI is estimated at 4 billion USD in 2018 (35.5\% of GDP).

In Ukraine, Foreign Direct Investment (FDI) is indisputably an important factor in stimulating economic growth. The data and analysis of the State Statistics Service of Ukraine reveal that FDI flows to Ukraine in 2018 reached 2.87 billion USD and showed a slight increase compared to 2017 (from 2.51 billion USD). The total FDI stock in 2018 was estimated at 31.6 billion USD.

Analysis of recent research and publications.

S. Yakubovskiy, T. Rodionova and T. Derkach (2019) studied the impact of income from foreign investments on the formation of external economic positions of nine emerging market economies of Central and Eastern Europe and Latin America by using several approaches to assess financial stability. Countries, for which the investment income payouts are exceeding $100 \%$ of the direct investment inflows, are the Czech Republic and Poland. The Ukrainian ratio of investment income payments to FDI was the smallest among the studied countries, but this is explained by the active use of non-market transfer pricing in trade operations between the Ukrainian affiliates and their "parent" companies that lead to a reduction of the official income of foreign affiliates in Ukraine [1].

T. Rodionova (2015) conducted an analysis of the structure and dynamics of the investment income of current account in CEE countries and Latin America. Nominally, the largest amounts of foreign capital were received by Russia, Brazil and Mexico. However, the share of exported income in total receipts was about $80 \%$ in Russia and Brazil, and about $60 \%$ in Mexico. In Ukraine and Georgia, the coverage ratio for FDI was the lowest among all the countries studied - at about $20 \%$. The countries of the Balkan 
group occupy an average position in terms of the share of exported income from FDI - a range of 40 to $70 \%$ [2].

D. Saha, V. Kravchuk, R. Kirchner (2018) studied the economic impact of FDI on Ukrainian economy. They did empirical analysis, which is based on a unique Ukrstat dataset, shows conclusively that FDI does play an important economic role for Ukraine. Although the inward FDI stock of Ukraine has declined by about 30-60 \% (in USD value, according to different sources) since 2013 due to a combination of currency depreciation and the economic crisis, our analysis demonstrates that companies with FDI contribute strongly to Ukraine's economy [3].

The purpose of the article is to assess the financial sustainability of countries, impact of investment on external debt and to determine the coverage ratio of foreign investments imported into countries and their profitability.

Research methodology. According to the methodology of T. A. Rodionova [2], it is possible to determine the foreign investment coverage ratio, which makes it possible to calculate the share of total income exported by investors in the corresponding cumulative receipts to the financial account The calculation formula looks like this:

$$
\text { Cover }^{x}=\frac{\sum I N C d_{t}^{x}}{x l^{t}}
$$

where Cover is the coefficient of coverage of foreign investments of type $\mathrm{x}$ for a certain period of time (for the countries that are presented in this paper, the coefficient was calculated for 2000-2019).

The return on foreign investment in countries will be calculated using formula 2 . The payment of investment income by a country in a foreign currency is designated as INCdtx, which is the debit of the current account income item for $\mathrm{x}$ - type obligations-direct, portfolio or other investments. The foreign currency yield on the liability can then be written as:

$$
Y L I_{t}^{x}=\frac{I N C d_{t}^{x}}{X L I_{t-1}}
$$

where XLI is the accumulation of external liabilities of type $X$, i.e., the international investment position.

Also a vector auto-regression model (VAR) will be used to identify the mutual causality between external public debt and income from direct, portfolio and other investments (over the period of 2000-2019). The Granger test will be represented by the following formula:

$$
\begin{gathered}
E D_{t}=\alpha_{1}+\sum_{i=1}^{p} \beta_{1 i} I n c_{t-i}+\sum_{i=1}^{p} \gamma_{1 i} E D_{t-i}+\varepsilon_{1 t} \\
I n c_{t}=\alpha_{2}+\sum_{i=1}^{p} \beta_{2 i} E D_{t-i}+\sum_{i=1}^{p} \gamma_{2 i} I n c_{t-i}+\varepsilon_{2 t}
\end{gathered}
$$

where $E D_{t}$ is the external debt to GDP, Inc is the income for each type of investment (direct, portfolio, others); $\alpha$ is a constant term; $\beta$ and $\gamma$ denote the coefficients to be evaluated, $\mathrm{p}$ is the selected lag order.

Results. The analysis of the structure of export of investment income from Georgia, Moldova and Ukraine is presented in Table 1. According to them, the share of FDI in the total export of income is $66 \%$ in Georgia and $67 \%$ in Moldova. In Ukraine, this figure is only $37.38 \%$, which is almost 2 times less than the above-mentioned countries.

Results. The analysis of the structure of export of investment income from Georgia, Moldova and Ukraine is presented in Table 1. According to them, the share of FDI in the total export of income is $66 \%$ in Georgia and $67 \%$ in Moldova. In Ukraine, this figure is only $37.38 \%$, which is almost 2 times less than the above-mentioned countries.

\section{Structure of investment income (in billion USD)}

for 2000-2019

\begin{tabular}{|l|c|c|c|}
\hline \multicolumn{1}{|c|}{ Country } & FDI & Portfolio & Other \\
\hline Georgia & $10.6(66 \%)$ & $1.36(8 \%)$ & $4.06(26 \%)$ \\
\hline Moldova & $2.61(67 \%)$ & $0.14(3.5 \%)$ & $1.14(29.5 \%)$ \\
\hline Ukraine & $37.38(35 \%)$ & $24.12(23 \%)$ & $44.5(42 \%)$ \\
\hline
\end{tabular}

Source: compiled by the author based on [4]

Portfolio investment repayments were only $8 \%$ in Georgia (share repayments are less than $1 \%$ ) and $3.5 \%$ in Moldova ( $2 \%$ share repayments and $2 \%$ debt repayments). In Ukraine, this figure was much higher $-23 \%$. The share of payments for other investments is $26 \%$ in Georgia, $29.5 \%$ in Moldova and $42 \%$ in Ukraine.

The next important indicator is the return on investment ratios that foreign investors received from investments in Georgia, Moldova and Ukraine.

Table 2

The ratio of the yield of attracted investments to Georgia, Moldova and Ukraine for 2000-2019

\begin{tabular}{|l|c|c|c|}
\hline \multicolumn{1}{|c|}{ Country } & FDI & Portfolio & Other \\
\hline Georgia & $6 \%$ & $4.7 \%$ & $3.1 \%$ \\
\hline Moldova & $4.4 \%$ & $7.7 \%$ & $1.8 \%$ \\
\hline Ukraine & $4.1 \%$ & $6.7 \%$ & $3.2 \%$ \\
\hline
\end{tabular}

Source: compiled by the author based on [4]

According to Table 2, the highest return on investment for the period 2000-2019 was received by investors in Moldova for portfolio investments $(7.7 \%)$, which is a fairly good indicator. Ukraine also recorded a high indicator for portfolio investments $(6.7 \%)$. In Georgia, investors received the highest return on direct investment $(6 \%)$. It should be noted that the lowest rate of return in the countries was recorded with other investments (3.1\% in Georgia, $3.2 \%$ in Ukraine and $1.8 \%$ in Moldova). This may also indicate that the risks of these investments are minimal.

According to the analysis in Table 3, Ukraine received the largest amount of foreign capital but the share of exported income in the total capital inflow was $48.03 \%$, while in Georgia $-47.45 \%$, and in Moldova $-36.97 \%$. FDI accounts for $51.13 \%$ of the received capital in Georgia, and $48.6 \%$ in Moldova and $43.36 \%$ in Ukraine.

Foreign investors received the least $39.42 \%$ of portfolio investments from Georgia, but $61 \%$ from Ukraine and $269 \%$ from Moldova. From other investments foreign investors received $42.33 \%$ from Georgia, and $21.65 \%$ from Moldova, but in Ukraine this figure was $46.92 \%$.

Next, we will look at such macroeconomic indicators as the net investment position and the amount of external debt. There is the following approach to assessing financial stability based on net investment position: if the ratio of net investment position to GDP is less than $36 \%$, then these countries can be considered as countries with a high level of financial stability in various financial crises, and so on.

Analysing the indicator of Georgia's net investment position, it should be noted that the country's dependence on investment is increasing (in 2000, the \% ratio to GDP was $-69.93 \%$, and in $2019-(-118.95)$ ) (Table 4). Moldova and Ukraine, on the contrary, have a decrease in dependence on foreign investment (-112.4\% of GDP in 2000 and $-42.33 \%$ in 2019 in Moldova) (-40.92 \% of GDP in 2000 and $-14.81 \%$ of GDP in 2019 in Ukraine). Thus, it can be noted that Georgia is becoming more and more dependent on foreign investment, 
Share of total income exported by foreign investors in the corresponding cumulative receipts of the financial account (foreign investment coverage ratio), for the period 2000-2019 in Georgia, Moldova and Ukraine

\begin{tabular}{|l|c|c|c|c|c|c|}
\hline \multicolumn{1}{|c|}{ Country } & FDI & Portfolio & Other & $\begin{array}{c}\text { Total exported } \\
\text { revenues in } \\
\text { millions of } \\
\text { dollars }\end{array}$ & $\begin{array}{c}\text { Cumulative } \\
\text { financial account } \\
\text { receipts USD } \\
\text { million }\end{array}$ & $\begin{array}{c}\text { The share of } \\
\text { exported revenues } \\
\text { in total revenues }\end{array}$ \\
\hline Georgia & $51.13 \%$ & $39.42 \%$ & $42.33 \%$ & 16026 & 33777 & $47.45 \%$ \\
\hline Moldova & $48.6 \%$ & $269 \%$ & $22.39 \%$ & 3890 & 10520 & $36.97 \%$ \\
\hline Ukraine & $43.36 \%$ & $61 \%$ & $46.92 \%$ & 105995 & 220692 & $48.03 \%$ \\
\hline
\end{tabular}

Source: compiled by the author based on [4]

Table 4

Macroeconomic indicators of Georgia, Moldova and Ukraine (in \% of GDP)

\begin{tabular}{|l|c|c|c|c|c|c|}
\hline \multirow{2}{*}{ Country } & \multicolumn{2}{|c|}{ International Investment Position } & \multicolumn{3}{c|}{ External debt } \\
\cline { 2 - 7 } & $\mathbf{2 0 0 0}$ & $\mathbf{2 0 0 9}$ & $\mathbf{2 0 1 9}$ & $\mathbf{2 0 0 0}$ & $\mathbf{2 0 0 9}$ & $\mathbf{2 0 1 9}$ \\
\hline Georgia & -69.93 & -100.55 & -118.95 & 71.77 & 83.2 & 105.86 \\
\hline Moldova & -112.4 & -39.15 & -42.33 & 133.77 & 82.24 & 62.88 \\
\hline Ukraine & -40.92 & -29.86 & -14.81 & 42.98 & 85.09 & 79.16 \\
\hline
\end{tabular}

Source: Compiled by the author based on $[4 ; 5 ; 6]$

while in Ukraine the net investment position indicator is improving and the country is more financially stable than Georgia and Moldova.

There is another approach based on estimating the value of external debt instruments and securities in GDP. If the ratio of external debt to external debt is less than $48 \%$, it can be considered financially stable to financial shocks.

Georgia's external debt in 2000 was $71.77 \%$ of GDP. However, in recent years, the situation has worsened - in 2019; this figure was $105.86 \%$ of GDP (this can be partly explained by an increase in FDI flows to countries). In Moldova, the situation is better - there is a reduction in external debt and in 2019 it amounted to $62.88 \%$ of GDP. In Ukraine, the external debt increased, when compared with the figures 2000 and 2009, but in 2019 it was reduced and it amounted to $79.16 \%$ of GDP. Thus, it can be noted that all 3 countries can be considered financially unstable to financial shocks.

Now we will use a vector auto-regression model (VAR) to identify the mutual causality between external public debt and income from direct, portfolio and other investments (over the period of 2000-2019 years).

Mutual causality between external public debt and income from direct, portfolio and other investments (over the period of 2000-2019 years)

\begin{tabular}{|l|c|c|c|}
\hline \multirow{2}{*}{ Country } & \multicolumn{3}{|c|}{ Lags } \\
\cline { 2 - 4 } & DI income & PI income & OI income \\
\hline Georgia & 0.0219 & 0.0215 & 0.0261 \\
\hline Moldova & 0.4586 & 0.0772 & 0.0032 \\
\hline Ukraine & 0.7642 & 0.6517 & 0.8389 \\
\hline
\end{tabular}

Source: compiled by the author

Having conducted the Granger test, it can be noted that the increase in Georgia's external debt is mostly influenced by direct and portfolio investments, but the impact of other investments is also significant. For Moldova, there is a mutual causality between the level of external debt and the income of portfolio and other investments. At the same time, the model did not show the relationship between Ukrainian external debt and investment income.

Conclusions. After the study, the following conclusions can be drawn. Direct investments dominate in the structure of investment income of Georgia and Moldova, while in Ukraine, the share of other investments is higher. The highest return on investment for the period 2000-2019 was received by investors in Moldova for portfolio investments $(7.7 \%)$, which was a fairly good indicator. Ukraine also recorded a high indicator for portfolio investments $(6.7 \%)$. In Georgia, investors received the highest return on direct investment $(6 \%)$. It should be noted that the lowest rate of return in the countries was recorded with other investments $(3.1 \%$ in Georgia, $3.2 \%$ in Ukraine and $1.8 \%$ in Moldova). Ukraine received the largest amount of foreign capital. But the share of exported income in the total capital inflow was $48.03 \%$, while in Georgia $47.45 \%$, and in Moldova - 36.97 \%. FDI accounts for $51.13 \%$ of the received capital in Georgia, and $48.6 \%$ in Moldova and $43.36 \%$ in Ukraine.

A comparative analysis based on net investment position to GDP shows that Georgia is becoming more and more dependent on foreign investment, while in Ukraine, the net investment position indicator is improving and the country is more financially sustainable than Georgia and Moldova. Another approach based on estimating the value of external debt instruments and securities in GDP showed that all 3 countries can be considered financially unstable to financial shocks.

Vector auto-regression model (VAR) showed that the increase in Georgia's external debt is mostly influenced by direct and portfolio investments, but the impact of other investments is also significant. For Moldova, there is a mutual causality between the level of external debt and the income of portfolio and other investments. At the same time, the model did not show the relationship between Ukrainian external debt and investment income.

\section{References:}

1. Yakubovskiy S., Rodionova T. and Derkach T. (2019), Impact of Foreign Investment Income on External Positions of Emerging Market Economies, Journal Transition Studies Review: Vol. 26 No. 1 [Electronic resource]. Access mode: https://transitionacademiapress.org/jtsr/article/view/241. (accessed 24 June 2020). 
2. Rodionova T. (2015), Return on Foreign Investment in Emerging Market Countries: Influence on External Imbalances: monograph / T. A. Rodionova, Odessa : «Odessa national University named after I. I. Mechnikov», 2015. 173 p. [Electronic resource]. Access mode: http://fs.onu.edu.ua/clients/client11/web11/pdf/rodion-inoz-invest.pdf. (accessed 23 June 2020).

3. Saha D., Kravchuk V., Kirchner R. (2018), The economic impact of FDI on Ukraine, Institute for Economic Research and Policy Consulting, Policy Studies Series [PS/01/2018]. - 51 p. [Electronic resource]. Access mode: http://www.ier.com.ua/files/ publications/Policy papers/German advisory group/2018/Full PS 01 2018 en.pdf. (accessed 24 June 2020).

4. IMF, Balance of Payments and International Investment Position statistics [Electronic resource]. Access mode: http://data.imf.org/?sk=7a51304b-6426-40c0-83dd-ca473ca1 fd52\&sId=1390030341854. (accessed 24 June 2020).

5. Trading economics, External debt statistics [Electronic resource]. Access mode: https://tradingeconomics.com/country-list/ external-debt. (accessed 24 June 2020).

6. World Bank, GDP (current US\$) [Electronic resource]. Access mode: https://data.worldbank.org/indicator/NY.GDP.MKTP.CD. (accessed 24 June 2020).

\section{ВПЛИВ ПРИБУТКОВОСТІ ІНОЗЕМНИХ ІНВЕСТИЦЙ НА ЗОВНІШНЬОЕКОНОМІЧНІ ПОЗИЦІЇ ГРУЗІї, МОЛДОВИ ТА УКРАЇНИ}

Анотація. У даній статті аналізується структура і вплив інвестиційного доходу від іноземних інвестицій на зовнішньоекономічні позиції Грузії, Молдови та України, а також фінансова стійкість країн. Аналіз структури експортних доходів від експорту з Грузії, Молдови та України показав, що частка ПІІ в загальному обсязі експорту становить 66 \% в Грузії і 67 \% в Молдові. В Україні цей показник становить всього 37,38 \%. Найбільшу віддачу від інвестицій за період 2000-2019 рр. Отримали інвестори в Молдові за портфельними інвестиціями $(7,7$ \%), що є досить хорошим показником. В Україні також зафіксовано високий показник портфельних інвестицій $(6,7$ \%). У Грузії інвестори отримали найбільшу віддачу від прямих інвестицій (6 \%). Найнижча норма прибутку в цих країнах була зафіксована 3 іншими інвестиціями. Україна отримала найбільший обсяг іноземного капіталу. Але частка експортних доходів у загальному припливі капіталу склала $48,03 \%$, в той час як в Грузії - 47,45\%, а в Молдові - 36,97 \%. На частку ПІІ припадає 51,13 \% отриманого капіталу в Грузії, 48,6 \% - в Молдові і 43,36 \% - в Україні. Найменше 39,42 \% портфельних інвестицій іноземні інвестори отримали з Грузії, але 61\% - 3 України і $269 \%$ - 3 Молдови. 3 інших інвестицій іноземні інвестори отримали 42,33 \% з Грузії і 21,65 \% з Молдови, але в Україні цей показник склав 46,92 \%.

Порівняльний аналіз, заснований на чистій інвестиційної позиції по відношенню до ВВП, показує, що Грузія стає все більш залежною від іноземних інвестицій, в той час як в Україні поліпшується показник чистої інвестиційної позиції, і країна фінансово стійкіше, ніж Грузія і Молдова. Інший підхід, заснований на оцінці вартості зовнішніх боргових інструментів і цінних паперів в ВВП, показав, що всі 3 країни можуть вважатися фінансово нестійкими до фінансових потрясінь.

Модель векторної авторегресії (VAR) показала, що на збільшення зовнішнього боргу Грузії в основному впливають прямі і портфельні інвестиції, але вплив інших інвестицій також є значним. Для Молдови існує взаємозалежність між рівнем зовнішнього боргу і доходами від портфеля та інших інвестицій. У той же час модель не показала взаємозв'язку між українським зовнішнім боргом і інвестиційним доходом.

Ключові слова: іноземні інвестиції, зовнішні позиції, борг, дохід, виплати.

\section{ВЛИЯНИЕ ПРИБЫЛЬНОСТИ ИНОСТРАННЫХ ИНВЕСТИЦИЙ НА ВНЕШНЕЭКОНОМИЧЕСКИЕ ПОЗИЦИИ ГРУЗИИ, МОЛДОВЫ И УКРАИНЫ}

Аннотация. В данной статье анализируется структура и влияние инвестиционных доходов от иностранных инвестиций на внешнеэкономические позиции Грузии, Молдовы и Украины, а также на финансовую стабильность стран. Сравнительный анализ, основанный на соотношении чистой инвестиционной позиции к ВВП, показал, что Грузия становится все более зависимой от иностранных инвестиций, в то время как в Украине показатель чистой инвестиционной позиции улучшается и страна является более финансово устойчивой, чем Грузия и Молдова. Векторная авторегрессионная модель (VAR) показала, что на увеличение внешнего долга Грузии в основном влияют прямые и портфельные инвестиции. Для Молдовы существует взаимная причинно-следственная связь между уровнем внешнего долга и доходами портфельных и других инвестиций. В то же время модель не показала взаимосвязи между внешним долгом Украины и инвестиционными доходами.

Ключевые слова: иностранные инвестиции, внешние позиции, долг, доход, выплаты. 